\title{
Tuna by-product meal as a dietary protein source replacing fishmeal in juvenile Korean rockfish Sebastes schlegeli
}

\author{
Kyoung-Duck Kim"D, Ji Won Jang ${ }^{2}$, Kang-Woong Kim², Bong-Joo Lee², Sang Woo Hur ${ }^{2}$ and Hyon-Sob Han ${ }^{3}$
}

\begin{abstract}
This study was conducted to evaluate the use of tuna by-product meal (TBM) as a substitute for fishmeal in juvenile Korean rockfish (Sebastes schlegeli) diets. Five isonitrogenous (52\% crude protein) and isocaloric $(4.9 \mathrm{kcal} / \mathrm{g})$ diets were prepared. Control diet (Con) was formulated to contain brown fishmeal, whereas 25, 50, 75, and 100\% of fishmeal was substituted with the same percentage of TBM in the TBM25, TBM50, TBM75, and TBM100 diets, respectively. Three replicate groups of fish (initial weight, $29.5 \pm 0.6 \mathrm{~g}$ ) were fed one of the five diets for 12 weeks. The mean weight gain of fish fed the Con and TBM25 diets was significantly higher than that of fish fed the TBM100 diet $(P<0.05)$, but it was not significantly different from the weight gain of fish fed the TBM50 and TBM75 diets. The feed efficiency and protein efficiency ratios of fish fed the Con diet were significantly higher than those of fish fed the TBM100 diet $(P<0.05)$, but were not significantly different from those fed the TBM25, TBM50, and TBM75 diets. The TBM25, TBM50, TBM75, and TBM100 diets had significantly $(P<0.05)$ lower incidence cost and higher profit index than the Con diet. These results suggest that the tuna by-product meal used in this study could replace up to $75 \%$ of fishmeal protein in the diet without reducing growth and feed utilization in juvenile Korean rockfish weighing 29-53 g. By considering feed cost, the TBM 75 diet is recommendable for Korean rockfish farming.
\end{abstract}

Keywords: Korean rockfish, Sebastes schlegeli, Fishmeal, Tuna by-product meal, Dietary protein, Growth

\section{Background}

Fishmeal is the most important protein source for fish culture feed due to its high-protein content and good balance of essential amino acids. In addition, it can improve fish feed palatability. High-quality fishmeal used in Korea is mainly imported from South American countries such as Chile (KITA 2016). Their prices are unstable, generally increasing due to fluctuations of raw fish catches.

Korean rockfish are the most abundant domestic aquaculture species along with flounder (Statistics Korea 2016). Korean rockfish have high dietary protein requirements (Lee et al. 2002). Considerable amounts of protein sources such as fishmeal are needed for rockfish feed. High contents of good quality fishmeal in diets generally result in improved fish growth and feed efficiency

\footnotetext{
* Correspondence: kimkd92@korea.kr

${ }^{1}$ Aquaculture Management Division, National Institute of Fisheries Science, Busan 46083, Republic of Korea

Full list of author information is available at the end of the article
}

(Vergara et al. 1999). Since fishmeal is expensive ingredients, using large amounts of them in diets can increase feed price. Considering both price and quality of fishmeal, it is very important for efficient fish culture management to use proper fishmeal in diets to reduce feed costs while improving the growth of cultured fish.

Previous studies have examined the use of animal and plant protein source as alternative to fishmeal for Korean rockfish feed (Lim et al. 2004), including the utilization of tuna by-product meal prepared by fermenting a mixture of tuna meal and soybean meal (Jeon et al. 2014).

Nutrient contents in tuna by-product meals such as protein and essential amino acids are slightly lower than those in high-quality fishmeal imported from South America, reflecting economics. Domestic feed companies that produce formulated feeds for Korean rockfish use tuna by-product meal as a portion of dietary protein source. However, there is limited research on the utilization of tuna by-product meal prepared without 
mixing plant protein sources in this species. The present study was conducted to investigate proper inclusion levels of tuna by-product meal without plant protein sources as a substitute of fishmeal for juvenile Korean rockfish diets.

\section{Methods}

\section{Experimental diets}

Proximate composition and amino acid composition of brown fishmeal and tuna by-product meal (Woojin Feed Ind. Co., Ltd., South Korea) used as protein sources in the experimental diets are shown in Table 1. Tuna by-product was prepared using tuna the heads, bones, fins, blood, and skin following the manufacture of canned Skipjack tuna (Katsuwonus pelamis) and Yellowfin tuna (Thunnus albacares). Tuna by-product meal was produced by routine method as follows. Raw materials were cooked by steaming $\left(100-105^{\circ} \mathrm{C}\right)$. They were compressed to separate oil. Subsequently, these materials were dried (100-105 ${ }^{\circ} \mathrm{C}$ ) and pulverized. Five isonitrogenous (52\% crude protein) and isocaloric $(4.9 \mathrm{kcal} / \mathrm{g})$ diets were prepared. Brown fishmeal (Chile) was included as control

Table 1 Nutrient contents (\%, DM) of dietary ingredients

\begin{tabular}{|c|c|c|}
\hline & Brown fishmeal $^{a}$ & Tuna by-product meal $^{b}$ \\
\hline \multicolumn{3}{|c|}{ Proximate composition } \\
\hline Crude protein & 77.2 & 64.6 \\
\hline Crude lipid & 8.2 & 9.6 \\
\hline Ash & 13.7 & 21.4 \\
\hline \multicolumn{3}{|c|}{ Indispensable amino acids } \\
\hline Arginine & 4.0 & 3.5 \\
\hline Cysteine & 0.7 & 0.6 \\
\hline Histidine & 2.9 & 1.7 \\
\hline Isoleucine & 3.1 & 2.5 \\
\hline Leucine & 5.1 & 4.1 \\
\hline Lysine & 5.5 & 4.3 \\
\hline Methionine & 2.2 & 1.8 \\
\hline Phenylalanine & 3.0 & 2.2 \\
\hline Threonine & 3.0 & 2.5 \\
\hline Valine & 3.6 & 2.7 \\
\hline \multicolumn{3}{|c|}{ Dispensable amino acids } \\
\hline Alanine & 4.2 & 3.8 \\
\hline Aspartic acid & 6.3 & 5.0 \\
\hline Glutamic acid & 8.9 & 6.9 \\
\hline Glycine & 4.1 & 4.2 \\
\hline Proline & 2.8 & 3.4 \\
\hline Serine & 2.8 & 2.4 \\
\hline Tyrosine & 2.4 & 1.8 \\
\hline
\end{tabular}

Imported from Chile

${ }^{\text {bS }}$ upplied by Woojin Feed Ind. Co., Ltd., Incheon Metropolitan City, South Korea
(Con) diet. Fishmeal comprising 25, 50, 75, and 100\% crude protein were substituted with the same percentage as crude protein in TBM25, TBM50, TBM75, and TBM100, respectively (Table 2). Squid liver oil and wheat flour were used as respective lipid and carbohydrate sources of diets. Experimental diets were prepared with a laboratory pellet machine after $35-40 \mathrm{ml}$ of water was mixed with $100 \mathrm{~g}$ mixture of ingredients. All diets were dried for $48 \mathrm{~h}$ at room temperature and freezer-stored $\left(-24{ }^{\circ} \mathrm{C}\right)$.

\section{Experimental fish and rearing conditions}

Korean rockfish (Sebastes schlegeli) obtained from a local fish farm (Tongyoung, Korea) were acclimated to laboratory conditions for 2 weeks before feeding trial. Experimental fish with an average initial body weight of $29.5 \pm 0.6 \mathrm{~g}$ were randomly distributed into each of 15 cylindrical plastic tanks (400 L, 30 fish per tank) with a flow-through system. Three replicate groups of fish were hand-fed experimental diets to apparent satiation once daily (10:00, 6 days a week) (Lee et al. 2000) for 12 weeks. Mean water temperature during the rearing period was $16.6 \pm 2.7^{\circ} \mathrm{C}$. All fish in each tank were weighed collectively at the beginning and the end of the feeding trial after $48 \mathrm{~h}$ fast.

\section{Sample collection and chemical analysis}

At the end of the feeding trial, ten fish were taken from each experimental tank and stored in a freezer $\left(-24{ }^{\circ} \mathrm{C}\right)$ for chemical analysis. Moisture contents of experimental diets and fish were measured after drying at $135{ }^{\circ} \mathrm{C}$ for $2 \mathrm{~h}$. Crude protein content $(N \times 6.25)$ was analyzed using an Auto Kjeldahl System (Gerhardt VAP50SC/KBL20, Germany). Crude lipid level was measured after extraction with ether employing a crude lipid extractor (Velp SER148, Italy). Ash content was determined following burning at $600{ }^{\circ} \mathrm{C}$ for $4 \mathrm{~h}$ using a muffle furnace. Gross energy of the experimental diet was analyzed using a calorimeter (PARR 6400, USA). Amino acid contents of experimental diets and fish were analyzed using an amino acid automatic analyzer (Biochrom $30^{+}$, England). Lipid for fatty acid analyses was extracted by a mixture of chloroform and methanol $(2: 1, v / v)$ according to the method of Folch et al. (1957). Fatty acid methyl esters were prepared by transesterification with $14 \% \mathrm{BF}_{3}-\mathrm{MeOH}$ (Sigma, St. Louis, MO, USA) and analyzed using a gas chromatograph (HP-6890 II; Hewlett-Packard, USA) equipped with a flame ionization detector and a HP-INNOWax capillary column $(30 \mathrm{~m} \times 0.32 \mathrm{~mm}$ i.d., film thickness $0.5 \mu \mathrm{m}$, Hewlett-Packard, USA). Injector and detector temperatures were set at 270 and $270{ }^{\circ} \mathrm{C}$, respectively. The column temperature was programmed from 170 to $225^{\circ} \mathrm{C}$ at a rate of $1{ }^{\circ} \mathrm{C} / \mathrm{min}$. Helium was used as carrier gas. Fatty acids were identified by comparison 
Table 2 Ingredients and proximate composition of experimental diets

\begin{tabular}{|c|c|c|c|c|c|}
\hline & \multicolumn{5}{|l|}{ Diets } \\
\hline & Con & TBM25 & TBM50 & TBM75 & TBM100 \\
\hline \multicolumn{6}{|l|}{ Ingredients (\%) } \\
\hline Brown fishmeal ${ }^{a}$ & 64.8 & 48.6 & 32.4 & 16.2 & \\
\hline Tuna by-product meal & & 19.3 & 38.7 & 58.1 & 77.5 \\
\hline Squid liver oil & 4.6 & 4.1 & 3.6 & 3 & 2.5 \\
\hline a-Cellulose & 10.6 & 8 & 5.3 & 2.7 & \\
\hline Wheat flour & 18 & 18 & 18 & 18 & 18 \\
\hline Vitamin premix ${ }^{\mathrm{b}}$ & 1 & 1 & 1 & 1 & 1 \\
\hline Mineral premix ${ }^{c}$ & 1 & 1 & 1 & 1 & 1 \\
\hline \multicolumn{6}{|l|}{ Proximate composition (\%, DM) } \\
\hline Crude protein & 52.7 & 52.6 & 52.6 & 52.6 & 52.6 \\
\hline Crude lipid & 9.9 & 10.1 & 10.5 & 10.3 & 10.6 \\
\hline Ash & 10.3 & 11.7 & 13.9 & 15.4 & 17.1 \\
\hline Gross energy (cal/g diet) & 4949 & 4918 & 4852 & 4876 & 4830 \\
\hline Feed price (won/kg feed, DM) ${ }^{d}$ & 1903 & 1789 & 1674 & 1558 & 1443 \\
\hline \multicolumn{6}{|c|}{ 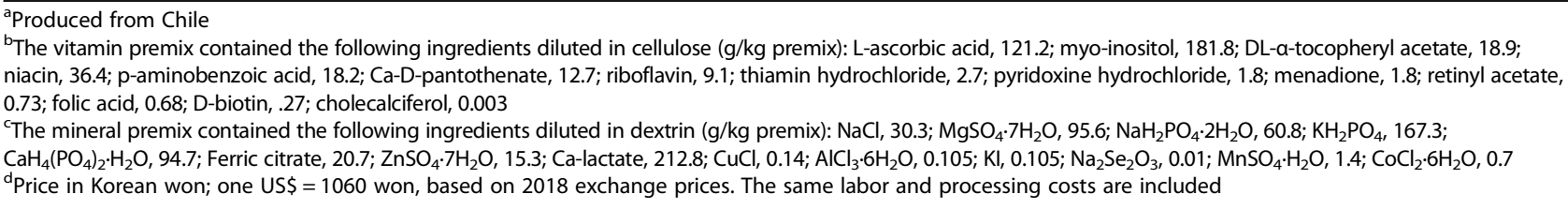 } \\
\hline
\end{tabular}

with known standards. Amino acids and fatty acid compositions of experimental diets are shown Tables 3 and 4, respectively.

\section{Statistical analyses}

Statistical analyses were performed using one-way analysis of variance (ANOVA) followed by Duncan's multiple range test (Duncan 1955). SPSS version 11.5 (SPSS, Chicago, IL, USA) was employed for all statistical analyses. Statistical significance was considered at $p<0.05$.

\section{Results}

Crude protein and essential amino acid contents of tuna by-product meal used as substitute of fishmeal in diets were slightly lower than those of brown fishmeal (Table 2). Growth performance and cost-benefit analyses of juvenile Korean rockfish fed experimental diets for 12 weeks are shown in Table 5. Survival rates of all experimental groups were 93-99\%, without showing significant differences among groups. Weight gain and specific growth rate of fish fed Con and TBM25 diets were not significantly different from those of fish fed TBM50 or TBM75 diet. However, they were significantly $(p<0.05)$ higher than those of fish fed TBM100 diet. Feed efficiency and protein efficiency of fish fed Con diet were significantly $(p<0.05)$ higher than those of fish fed TBM100 diet. However, they were not significantly different from those of fish fed TBM25, TBM50, or TBM75 diet. Daily feed intake was significantly $(p<0.05)$ influenced by experimental diets. TBM25, TBM50, TBM75, and TBM100 diets had significantly $(p<0.05)$ lower incidence cost but higher profit index than the Con diet. TBM50, TBM75, and TBM100 diets were the best economically, followed by TBM25 and Con diets.

Proximate compositions of the whole body of juvenile Korean rockfish fed experiment diets are shown in Table 6. Moisture, crude protein, or ash contents were not significantly different among all experimental groups. However, crude lipid content was significantly $(p<0.05)$ influenced by experimental diets. Amino acid compositions of the whole body of fish at the end of feeding trial were not significantly different among experimental diet groups (Table 7).

\section{Discussion}

In this study, survival rates of fish in all experimental groups were over 93\%. There were no significant differences in growth or feed efficiency of fish fed Con, TBM25, TBM50, or TBM75 diet. This suggests that tuna by-product meal can replace $75 \%$ fishmeal protein without reducing growth or feed utilization in juvenile Korean rockfish (29-53 g). Since tuna by-product meal is less expensive than brown fishmeal, its use as a fishmeal substitute in practical feed is expected to lower feed costs without decreasing growth of juvenile Korean 
Table 3 Amino acids compositions (\%, DM) of experimental diets

\begin{tabular}{|c|c|c|c|c|c|}
\hline & Diets & & & & \\
\hline & Con & TBM25 & TBM50 & TBM75 & TBM100 \\
\hline Indispensable am & & & & & \\
\hline Arginine & 2.9 & 2.7 & 2.6 & 2.5 & 2.4 \\
\hline Cysteine & 0.4 & 0.4 & 0.4 & 0.4 & 0.4 \\
\hline Histidine & 2.2 & 1.9 & 1.7 & 1.7 & 1.3 \\
\hline Isoleucine & 2.3 & 2.1 & 2.1 & 1.9 & 1.9 \\
\hline Leucine & 3.7 & 3.4 & 3.4 & 3.2 & 3.1 \\
\hline Lysine & 4.0 & 3.7 & 3.6 & 3.4 & 3.1 \\
\hline Methionine & 1.5 & 1.3 & 1.4 & 1.3 & 1.2 \\
\hline Phenylalanine & 2.2 & 2.0 & 2.0 & 1.8 & 1.8 \\
\hline Threonine & 2.2 & 2.1 & 2.0 & 1.9 & 1.8 \\
\hline Valine & 2.6 & 2.5 & 2.5 & 2.2 & 2.1 \\
\hline Dispensable amir & & & & & \\
\hline Alanine & 3.1 & 3.0 & 3.0 & 2.9 & 2.9 \\
\hline Aspartic acid & 4.6 & 4.4 & 4.2 & 3.9 & 3.8 \\
\hline Glutamic acid & 7.1 & 6.5 & 6.3 & 6.1 & 5.6 \\
\hline Glycine & 3.1 & 3.0 & 3.1 & 3.2 & 3.2 \\
\hline Proline & 2.2 & 2.2 & 2.2 & 2.3 & 2.4 \\
\hline Serine & 2.0 & 2.0 & 1.9 & 1.8 & 1.7 \\
\hline Tyrosine & 1.2 & 1.3 & 1.2 & 1.3 & 1.3 \\
\hline
\end{tabular}

rockfish. In a previous study (Jeon et al. 2014), fishmeal could be replaced by tuna by-product meal prepared by fermenting a mixture of tuna fishmeal and soybean meal up to $40 \%$ without diminishing the growth of juvenile Korean rockfish (3-12 g), which is lower than the $75 \%$ replacement of fishmeal in this study. In previous studies on flounder, fishmeal could be replaced with tuna by-product meal prepared by fermenting a mixture of tuna fishmeal and soybean meal up to $30 \%$ without decreasing the growth of juvenile flounder (Kim et al. 2014). However, Uyan et al. (2006) have reported that tuna muscle by-product powder could replace $50 \%$ fishmeal without affecting growth performance of juvenile flounder. These differences in dietary substitution level of fishmeal with tuna by-product meal might be due to rearing conditions, fish sizes, inclusion of plant protein source such as soybean meal, nutrient contents such as essential amino acids, and digestibility of tuna by-product meal in diets. Lim et al. (2004) have reported that juvenile Korean rockfish (2.5 g initial weight) fed diets with $20 \%$ fishmeal replaced with soybean meal show reduced growth and feed efficiency compared to those fed with fishmeal-based control diet. Similar results of growth and feed efficiency were also observed in Korean rockfish with initial weight of $21.5 \mathrm{~g}$ fed diet having $20 \%$ fishmeal replaced with soybean meal and fishmeal-based control diet. A prior study on Korean rockfish (Lee 2002) has reported that apparent digestibility coefficients for dry matter, crude protein, and energy of soybean meal in juveniles (30 g) are lower than those in growers $(300 \mathrm{~g})$ while both juvenile and grower Korean rockfish fed with fishmeal show higher apparent digestibility coefficients for dry matter, crude protein, and energy compared to those fed with soybean meal. Therefore, the lower nutrient digestibility of soybean meal contained in tuna by-product meal reported in the study of Jeon et al. (2014) might have reflected the difference in dietary substitution level between fishmeal and tuna by-product meal for juvenile Korean rockfish. Yan et al. (2007) have reported that dietary methionine requirement for maximum growth of juvenile rockfish is $1.37 \%$ in the presence of $0.12 \%$ cysteine. Methionine content in diets used in the present study ranged from $1.2-1.5 \%$, which was higher than dietary methionine level of $0.76-1.0 \%$ in the study of Jeon et al. (2014). These differences in dietary methionine levels might have affected the growth of rockfish.

In the present study, juvenile Korean rockfish fed TBM100 diet (i.e., 100\% replacement of fishmeal with tuna by-product meal) showed reduced growth and feed efficiency compared to those fed Con diet that contained only fishmeal as protein source. Contents of major 
Table 4 Fatty acids compositions of experimental diets

\begin{tabular}{|c|c|c|c|c|c|}
\hline & \multicolumn{5}{|l|}{ Diets } \\
\hline & Con & TBM25 & TBM50 & TBM75 & TBM100 \\
\hline \multicolumn{6}{|c|}{ Fatty acids (\% of total fatty acids) } \\
\hline C14:0 & 3.5 & 3.4 & 3.5 & 3.5 & 3.8 \\
\hline C16:0 & 18.4 & 19.5 & 20.3 & 21.7 & 25.1 \\
\hline C16:1n & 4.0 & 4.2 & 4.5 & 4.8 & 6.1 \\
\hline C18:0 & 6.9 & 7.1 & 7.1 & 7.2 & 7.3 \\
\hline C18:1n-9 & 20.7 & 20.6 & 21.2 & 20.9 & 20.6 \\
\hline C18:2n-6 & 19.0 & 17.5 & 16.8 & 15.7 & 12.2 \\
\hline C18:3n-3 & 4.9 & 4.5 & 4.4 & 4.1 & 3.1 \\
\hline $\mathrm{C} 20: 0$ & 0.7 & 0.7 & 0.7 & 0.7 & 0.8 \\
\hline C20:1n-9 & 1.0 & 1.2 & 2.0 & 2.2 & 2.3 \\
\hline$C 20: 4 n-6$ & 1.2 & 1.2 & 1.2 & 1.2 & 1.5 \\
\hline$C 20: 5 n-3$ & 5.0 & 4.9 & 4.5 & 4.4 & 4.3 \\
\hline $\mathrm{C} 22: 0$ & 0.8 & 1.0 & 1.2 & 1.3 & 1.3 \\
\hline$C 22: 5 n-3$ & 1.8 & 1.6 & 1.3 & 1.1 & 1.0 \\
\hline$C 22: 6 n-3$ & 12.3 & 12.5 & 11.4 & 11.2 & 10.7 \\
\hline \multicolumn{6}{|c|}{ Fatty acids (\% in diet, DM) } \\
\hline EPA & 0.44 & 0.44 & 0.42 & 0.40 & 0.40 \\
\hline $\mathrm{DHA}$ & 1.08 & 1.12 & 1.07 & 1.03 & 1.01 \\
\hline n-3HUFA & 1.68 & 1.71 & 1.61 & 1.53 & 1.51 \\
\hline
\end{tabular}

EPA eicosapentaenoic acid, DHA docosahexaenoic acid

${ }^{a}$ Fatty acids (\% in diet), calculated (dietary total lipid $\left.\times 0.892\right)$ (Yoshimatsu et al. 1997)

Table 5 Growth performance and cost-benefit analyses of juvenile Korean rockfish fed diets containing various levels of tuna by-product meal for 12 weeks

\begin{tabular}{|c|c|c|c|c|c|}
\hline & \multicolumn{5}{|l|}{ Diets } \\
\hline & Con & TBM25 & TBM50 & TBM75 & TBM100 \\
\hline Initial mean weight (g/fish) & $29.5 \pm 0.3^{\text {ns }}$ & $29.3 \pm 0.5$ & $29.2 \pm 0.4$ & $29.6 \pm 0.4$ & $29.5 \pm 0.2$ \\
\hline Survival (\%) & $98 \pm 1.1^{\mathrm{ns}}$ & $93 \pm 3.3$ & $99 \pm 1.1$ & $98 \pm 1.1$ & $96 \pm 4.4$ \\
\hline Mean weight gain (g/fish) & $23.5 \pm 0.8^{b}$ & $23.5 \pm 0.5^{b}$ & $21.3 \pm 0.6^{\mathrm{ab}}$ & $22.2 \pm 0.4^{\mathrm{ab}}$ & $19.7 \pm 1.3^{\mathrm{a}}$ \\
\hline Specific growth rate $(\% / \text { day })^{a}$ & $0.69 \pm 0.02^{b}$ & $0.69 \pm 0.01^{b}$ & $0.65 \pm 0.01^{\mathrm{ab}}$ & $0.66 \pm 0.01^{\mathrm{ab}}$ & $0.60 \pm 0.03^{\mathrm{a}}$ \\
\hline Feed efficiency $(\%)^{b}$ & $61 \pm 1.4^{b}$ & $61 \pm 1.1^{\mathrm{b}}$ & $63 \pm 1.1^{b}$ & $59 \pm 1.6^{\mathrm{b}}$ & $51 \pm 2.0^{\mathrm{a}}$ \\
\hline Protein efficiency ratio ${ }^{c}$ & $1.18 \pm 0.03^{b}$ & $1.20 \pm 0.02^{b}$ & $1.24 \pm 0.02^{b}$ & $1.17 \pm 0.03^{b}$ & $1.02 \pm 0.04^{\mathrm{a}}$ \\
\hline Daily feed intake ${ }^{d}$ & $1.08 \pm 0.01^{\mathrm{ab}}$ & $1.04 \pm 0.02^{\mathrm{ab}}$ & $.99 \pm 0.03^{\mathrm{a}}$ & $1.07 \pm 0.02^{\mathrm{ab}}$ & $1.11 \pm 0.04^{b}$ \\
\hline Incidence cost ${ }^{\mathrm{e}}$ & $3279 \pm 76.7^{c}$ & $2965 \pm 56.1^{b}$ & $2722 \pm 48.5^{\mathrm{ab}}$ & $2625 \pm 73.1^{\mathrm{a}}$ & $2819 \pm 107.2^{\mathrm{ab}}$ \\
\hline Profit index ${ }^{f}$ & $3.72 \pm 0.06^{\mathrm{a}}$ & $4.33 \pm 0.10^{b}$ & $4.86 \pm 0.15^{b c}$ & $4.86 \pm 0.09^{b c}$ & $5.25 \pm 0.32^{c}$ \\
\hline
\end{tabular}

Values (mean \pm SE of three replications) in each row that do not share a common superscript letter are significantly different $(P<0.05)$

${ }^{a}[\ln ($ finalbody weight) $-\ln ($ initial body weight) $] \times 100 /$ day

${ }^{\mathrm{b}}$ Fish wet weight gain $\times 100 /$ feed intake (dry matter)

${ }^{\mathrm{c}} \mathrm{Fish}$ wet weight gain/protein intake

${ }^{d}$ Feed intake (or protein) $\times 100 /($ initial fish wt. + final fish wt. + dead fish wt.) $\times$ days fed/2)

${ }^{\mathrm{e}}$ Cost of kilogram feed consumed/kg fish produced

fValue of fish crop (8300 won/kg)/cost of feed consumed

${ }^{\text {ns }}$ Not significant $(P>0.05)$ 
Table 6 Proximate composition (\%) of the whole body in juvenile Korean rockfish fed diets containing various levels of tuna by-product meal for 12 weeks

\begin{tabular}{llllll}
\hline & \multicolumn{1}{l}{ Diets } & & & \\
\cline { 2 - 5 } & Con & TBM25 & TBM50 & TBM75 & TBM100 \\
\hline Moisture & $67.2 \pm 0.35^{\mathrm{ns}}$ & $67.0 \pm 0.39$ & $67.4 \pm 0.24$ & $67.5 \pm 0.15$ & $67.3 \pm 0.41$ \\
Crude protein & $16.8 \pm 0.31^{\mathrm{ns}}$ & $17.2 \pm 0.22$ & $17.0 \pm 0.15$ & $17.1 \pm 0.19$ & $17.2 \pm 0.23$ \\
Crude lipid & $9.7 \pm 0.35^{\mathrm{b}}$ & $8.9 \pm 0.26^{\mathrm{ab}}$ & $8.5 \pm 0.33^{\mathrm{a}}$ & $9.1 \pm 0.23^{\mathrm{ab}}$ & $8.7 \pm 0.44^{\mathrm{ab}}$ \\
Ash & $4.9 \pm 0.42^{\mathrm{ns}}$ & $4.7 \pm 0.29$ & $4.8 \pm 0.09$ & $4.6 \pm 0.1$ & $4.7 \pm 0.29$ \\
\hline
\end{tabular}

Values (mean \pm SE of three replications) in each row that do not share a common superscript letter are significantly different $(P<0.05)$

${ }^{\text {ns }}$ Not significant $(P>0.05)$

nutrients such as essential amino acids were lower in tuna by-product meal than those in brown fishmeal diets. Growth and feed efficiency of fish can differ according to the quality of fishmeal in diets (Caballero et al. 1999). Fishmeal quality depends on nutrient contents and digestibility, freshness of raw materials, and processing conditions used for fishmeal manufacturing (Aksnes and Mundheim 1997). In the study of Aksnes and Mundheim (1997), Atlantic halibut showed slower growth when the freshness of materials for fishmeal in diets was decreased.

Most marine fish require $\mathrm{n}-3$ highly unsaturated fatty acids (HUFA) such as eicosapentaenoic acid and docosahexaenoic acid for normal growth and development (Furuita et al. 2002; Bell and Dick 2004). In a previous study by Lee (2001), n-3 HUFA requirement for optimum growth of juvenile Korean rockfish was reported to be at $0.9 \%$. As n-3 HUFA levels in experimental diets ranged from 1.51 to $1.71 \%$ in the present study, these could be used as sources of essential fatty acids in all diets to satisfy n-3 HUFA requirements of Korean rockfish.

Cost-benefit analyses including incidence cost and profit benefit of diets indicated that TBM was more economical than imported fishmeal because of this local availability at low prices.

Table 7 Amino acid composition (\%) of the whole body in juvenile Korean rockfish fed diets containing various levels of tuna by-product meal for 12 weeks

\begin{tabular}{|c|c|c|c|c|c|}
\hline & \multicolumn{5}{|l|}{ Diets } \\
\hline & Con & TBM25 & TBM50 & TBM75 & TBM100 \\
\hline \multicolumn{6}{|c|}{ Indispensable amino acids } \\
\hline Arginine & $1.07 \pm 0.03^{\text {ns }}$ & $0.91 \pm 0.01$ & $0.96 \pm 0.03$ & $0.97 \pm 0.09$ & $0.96 \pm 0.08$ \\
\hline Cysteine & $0.18 \pm 0.00^{\mathrm{ns}}$ & $0.17 \pm 0.02$ & $0.16 \pm 0.00$ & $0.18 \pm 0.02$ & $0.14 \pm 0.01$ \\
\hline Histidine & $0.39 \pm 0.01^{\mathrm{ns}}$ & $0.34 \pm 0.00$ & $0.34 \pm 0.01$ & $0.34 \pm 0.03$ & $0.36 \pm 0.03$ \\
\hline Isoleucine & $0.67 \pm 0.01^{\text {ns }}$ & $0.57 \pm 0.04$ & $0.65 \pm 0.02$ & $0.66 \pm 0.06$ & $0.75 \pm 0.14$ \\
\hline Leucine & $1.15 \pm 0.00^{\mathrm{ns}}$ & $0.98 \pm 0.04$ & $1.08 \pm 0.03$ & $1.10 \pm 0.09$ & $1.01 \pm 0.04$ \\
\hline Lysine & $1.27 \pm 0.01^{\mathrm{ns}}$ & $1.11 \pm 0.03$ & $1.17 \pm 0.03$ & $1.21 \pm 0.10$ & $1.17 \pm 0.09$ \\
\hline Methionine & $0.50 \pm 0.02^{\mathrm{ns}}$ & $0.48 \pm 0.04$ & $0.55 \pm 0.00$ & $0.50 \pm 0.05$ & $0.50 \pm 0.03$ \\
\hline Phenylalanine & $0.74 \pm 0.05^{\mathrm{ns}}$ & $0.63 \pm 0.04$ & $0.69 \pm 0.02$ & $0.64 \pm 0.07$ & $0.64 \pm 0.05$ \\
\hline Threonine & $0.74 \pm 0.01^{\mathrm{ns}}$ & $0.62 \pm 0.01$ & $0.68 \pm 0.02$ & $0.66 \pm 0.06$ & $0.66 \pm 0.06$ \\
\hline Valine & $0.76 \pm 0.02^{\mathrm{ns}}$ & $0.63 \pm 0.04$ & $0.73 \pm 0.02$ & $0.73 \pm 0.07$ & $0.66 \pm 0.01$ \\
\hline \multicolumn{6}{|c|}{ Dispensable amino acids } \\
\hline Alanine & $1.05 \pm 0.09^{\text {ns }}$ & $0.92 \pm 0.03$ & $1.01 \pm 0.04$ & $1.01 \pm 0.08$ & $0.81 \pm 0.12$ \\
\hline Aspartate & $1.65 \pm 0.01^{\mathrm{ns}}$ & $1.38 \pm 0.03$ & $1.51 \pm 0.04$ & $1.51 \pm 0.14$ & $1.46 \pm 0.12$ \\
\hline Glutamate & $2.20 \pm 0.02^{\mathrm{ns}}$ & $1.89 \pm 0.03$ & $2.01 \pm 0.05$ & $2.02 \pm 0.19$ & $2.05 \pm 0.17$ \\
\hline Glycine & $1.47 \pm 0.08^{\mathrm{ns}}$ & $1.18 \pm 0.07$ & $1.26 \pm 0.08$ & $1.24 \pm 0.09$ & $1.28 \pm 0.10$ \\
\hline Proline & $0.87 \pm 0.04^{\mathrm{ns}}$ & $0.78 \pm 0.05$ & $0.81 \pm 0.05$ & $0.76 \pm 0.04$ & $0.84 \pm 0.09$ \\
\hline Serine & $0.79 \pm 0.02^{\mathrm{ns}}$ & $0.67 \pm 0.02$ & $0.72 \pm 0.03$ & $0.70 \pm 0.06$ & $0.72 \pm 0.06$ \\
\hline Tyrosine & $0.57 \pm 0.03^{\mathrm{ns}}$ & $0.50 \pm 0.03$ & $0.55 \pm 0.02$ & $0.54 \pm 0.06$ & $0.52 \pm 0.05$ \\
\hline
\end{tabular}

Values are the mean \pm SE of three replications

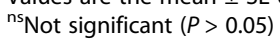


Moisture and crude protein contents of the whole body were not significantly affected by experimental diets in this study. In contrast, Jeon et al. (2014) have reported that increased tuna by-product meal substitution in diets tends to elevate moisture content but lower crude protein content in fish.

Although differences in essential amino acids such as histidine, leucine, and lysine in diets were observed, amino acid contents of the whole body were not significantly different among experimental groups in this study. In a prior study involving Korean rockfish (Jeon et al. 2014), contents of essential amino acids in juvenile rockfish were not affected by dietary tuna by-product meal levels. Similarly, Yamamoto et al. (2000) have reported that whole body amino acid compositions in rainbow trout fed with various dietary compositions do not show marked differences. These observations are expected because body proteins are synthesized based on genetic information from DNA. Thus, amino acid compositions of specific body proteins are the same irrespective of dietary treatments.

\section{Conclusions}

Tuna by-product meal used in this study could replace fishmeal protein up to $75 \%$ in the diet without reducing growth or feed utilization in juvenile Korean rockfish (29-53 g). By considering feed cost, the TBM 75 diet is recommendable for Korean rockfish farming.

\author{
Abbreviations \\ DHA: Docosahexaenoic acid; EPA: Eicosapentaenoic acid; HUFA: Highly \\ unsaturated fatty acids; KITA: Korea International Trade Association; \\ TBM: Tuna by-product meal
}

\section{Acknowledgements}

This work was supported by a grant (R2018005) from the National Institute of Fisheries Science, Republic of Korea.

\section{Funding}

This study was funded by the National Institute of Fisheries Science under Technology Development Program for Fisheries Research.

\section{Availability of data and materials}

All datasets generated and/or analyzed during the current study are available from the corresponding author on reasonable request.

\section{Authors' contributions \\ K-DK participated in research design, feeding trial, sample collection, data analysis, statistical analysis, and writing the paper. JWJ participated in chemical analysis, data analysis, and writing the paper. K-WK participated in research design, feeding trial, and sample collection. B-JL participated in research design, feeding trial, and sample collection. SWH participated in the data analysis and writing the paper. $\mathrm{H}$-SH participated in research design, data analysis, and writing the paper. All authors read and approved the final manuscript.}

\section{Ethics approval}

All experimental protocols followed guidelines of the Institutional Animal Care and Use provided by Committee of the National Institute of Fisheries and Science.
Consent for publication

Not applicable

\section{Competing interests}

The authors declare that they have no competing interests.

\section{Publisher's Note}

Springer Nature remains neutral with regard to jurisdictional claims in published maps and institutional affiliations.

\section{Author details}

${ }^{1}$ Aquaculture Management Division, National Institute of Fisheries Science, Busan 46083, Republic of Korea. ${ }^{2}$ Aquafeed Research Center, National Institute of Fisheries Science, Pohang 37517, Republic of Korea. ${ }^{3}$ Kunsan National University, Kunsan 54150, Republic of Korea.

Received: 12 February 2018 Accepted: 19 July 2018

Published online: 30 August 2018

\section{References}

Aksnes $\mathrm{A}$, Mundheim $\mathrm{H}$. The impact of raw material freshness and processing temperature for fish meal on growth, feed efficiency and chemical composition of Atlantic halibut (Hippoglossus hippoglossus). Aquaculture. 1997;149:87-106

Bell MV, Dick JR. Changes in capacity to synthesise 22:6n-3 during early development in rainbow trout (Oncorhynchus mykiss). Aquaculture. 2004;235:393-409.

Caballero MJ, López-Calero G, Socorro J, Roo FJ, Izquierdo MS, Férnandez AJ. Combined effect of lipid level and fish meal quality on liver histology of gilthead seabream (Sparus aurata). Aquaculture. 1999;179:277-90.

Duncan DB. Multiple-range and multiple F tests. Biometrics. 1955;11:1-42.

Folch J, Lees M, Sloane-Stanley GH. A simple method for the isolation and purification of total lipids from animal tissues. J Biol Chem. 1957:226:496-509.

Furuita $H$, Tanaka $H$, Yamamoto $T$, Suzuki N, Takeuchi T. Effects of high levels of n-3 HUFA in broodstock diet on egg quality and egg fatty acid composition of Japanese flounder, Paralichthys olivaceus. Aquaculture. 2002;210:323-33.

Jeon GH, Kim HS, Hyung SH, Cho SH. The effect of the dietary substitution of fishmeal with tuna by-product meal on growth, body composition, plasma chemistry and amino acid profiles of juvenile Korean rockfish (Sebastes schlegeli). Aquac Nutr. 2014;20:753-61.

Kim HS, Jung WG, Myung SH, Cho SH, Kim DS. Substitution effects of fishmeal with tuna byproduct meal in the diet on growth, body composition, plasma chemistry and amino acid profiles of juvenile olive flounder (Paralichthys olivaceus). Aquaculture. 2014;431:92-8.

KITA. Korea International Trade Association. Korea Trade Statistics; 2016. Retrieved from http://global.kita.net. Cited 21 Feb 2017

Lee SM. Review of the lipid and essential fatty acid requirements of rockfish (Sebastes schlegeli). Aquac Res. 2001;32:8-17.

Lee SM. Apparent digestibility coefficients of various feed ingredients for juvenile and grower rockfish (Sebastes schlegeli). Aquaculture. 2002;207:79-95.

Lee SM, Hwang UG, Choi SH. Effects of feeding frequency and dietary moisture content on growth, body composition and gastric evacuation of juvenile Korean rockfish (Sebastes schlegeli). Aquaculture. 2000;187:399-409.

Lee SM, Kim DJ, Choi SH. Effects of dietary protein and lipid level on growth and body composition of juvenile ayu (Plecoglossus altivelis) reared in seawater. Aquac Nutr. 2002;8:53-8.

Lim SR, Choi SM, Wang XJ, Kim KW, Shin IS, Min TS, Bai SC. Effects of dehulled soybean meal as a fish meal replacer in diets for fingerling and growing Korean rockfish Sebastes schlegeli. Aquaculture. 2004;231:457-68.

Statistics Korea. Fishery production survey. 2016. Retrieved from http://kostat.go.kr

Uyan O, Koshio S, Teshima SI, Ishikawa M, Thu M, Alam MS, Michael FR. Growth and phosphorus loading by partially replacing fishmeal with tuna muscle by-product powder in the diet of juvenile Japanese flounder, Paralichthys olivaceus. Aquaculture. 2006;257:437-45.

Vergara JM, Lopez-Calero G, Robaina L, Caballero MJ, Montero D, Izquierdo MS, Aksnes A. Growth, feed utilization and body lipid content of gilthead seabream (Sparus aurata) fed increasing lipid levels and fish meals of different quality. Aquaculture. 1999;179:35-4. 
Yamamoto T, Unuma T, Akiyama T. The influence of dietary protein and fat levels on tissue free amino acid levels of fingerling rainbow trout (Oncorhynchus mykiss). Aquaculture. 2000;182:353-72.

Yan Q, Xie S, Zhu X, Lei W, Yang Y. Dietary methionine requirement for juvenile rockfish Sebastes schlegeli. Aquac Nutr. 2007;13:163-9.

Yoshimatsu T, Imoto H, Hayash M, Toda K, Yoshimara K. Preliminary results in improve essential fatty acids enrichment of rotifer cultured in high density. Hydrobiologia. 1997;358:153-7. https://doi.org/10.1007/978-94-017-2097-7_23

Ready to submit your research? Choose BMC and benefit from:

- fast, convenient online submission

- thorough peer review by experienced researchers in your field

- rapid publication on acceptance

- support for research data, including large and complex data types

- gold Open Access which fosters wider collaboration and increased citations

- maximum visibility for your research: over $100 \mathrm{M}$ website views per year

At BMC, research is always in progress.

Learn more biomedcentral.com/submissions 